УДК 616.711-007.5-085.825-053.4

DOI 10.11603/2411-1597.2019.1.9977

\title{
ЕФЕКТИВНІСТЬ ЗАСТОСУВАННЯ ЛІКУВАЛЬНОЇ ФІЗКУЛЬТУРИ І МАСАЖУ ПРИ ПОРУШЕННЯХ ПОСТАВИ У ДІТЕЙ ДОШКІЛЬНОГО ВІКУ
}

\author{
I. Р. Мисула, В. В. Васильчук \\ ДвНЗ «Тернопільський державний медичний університет \\ імені І. Я. Горбачевського мОз Украӥни»
}

\begin{abstract}
Стаття присвячена вивченню особливостей порушення постави у дітей та виявленню методів фізичної реабілітації, які дають найбільш позитивний результат. Найефективнішим методом реабілітації дітей 3 викривленням хребта виявилося поєднання лікувальної фізкультури і масажу, на що вказувало швидше відновлення порушень постави. Зазначені методи фізичної реабілітації особливо були ефективними у дітей з початковими порушеннями постави, що свідчить про необхідність якнайшвидшого початку реабілітації.
\end{abstract}

\section{EFFECTIVENESS OF REHABILITATION EXERCISES AND MASSAGE IN PRESCHOOLERS WITH POSTURAL ABNORMALITIES}

\author{
I. R. Mysula, V. V. Vasylchuk
}

\section{Horbachevsky Ternopil State Medical University}

The article is devoted to the investiganions of the features of postural abnormalities in children and to the identification of methods of physical rehabilitation, which give the most positive result. The combination of rehabilitation exercises and massage is considered the most effective method of rehabilitation of children with spinal cord distortion, which is indicated by the rapid restoration of postural abnormalities. These methods of physical rehabilitation were particularly effective in children with initial posture disorders, which indicates the need for early onset of rehabilitation.

Вступ. На сьогодні велика кількість дітей страждає від хвороб опорно-рухового апарату, а саме викривлення хребетного стовпа. Незважаючи на те, що існує велика кількість методик фізичної реабілітації цієї патології, досить ефективними є масаж та лікувальна фізкультура. Однак на сьогодні не виявлено, яка з цих методик $\epsilon$ найефективнішою [1].

Мета дослідження: визначити у популяції дітей дитячого садка відсоток хворих на порушення постави та виявити методи фізичної реабілітації, які дають найпозитивніший результат.

Основна частина. Обстежено 60 дітей віком 4-6 років дитячого садка № 8 у м. Тернополі. У дослідженні застосовано методи огляду дітей та анкетування дітей і їх батьків. Оглядовим методом було отримано антропометричні результати, дані положення голови, рівня розташування плечей, наявності сутулості, зміщення трикутників талії та наявності перекосу таза [2]. Дітей поділили за ступенем сколіозу, застосувавши сколіо-

() І. Р. Мисула, В. В. Васильчук, 2019 метр. У дітей з порушеннями I ступеня відхилення сягали 10 градусів, II ступеня - до 25 градусів та зміни були помітні ззовні, III та IV ступенів - до 65 градусів і була помітна значна деформація грудної клітки та перекос таза [3, 4].

Усіх дітей з порушеннями постави поділили на 3 групи. 1-ша - діти, яким для реабілітації застосовували лікувальну фізкультуру (14 осіб) у вигляді різних ігор. Прикладом бути такі прості рухові дії, як стрибки, метання м'яча на відстань та повільний біг, який чергували з ходою. Вправи поєднували музичним супроводом для підтримання гарного настрою у дитини. За кожну добре виконану вправу дітям давали невеличкий приз, щоб зацікавити їх до подальшої продуктивної реабілітації. Заняття проводили щоденно, тривалістю 30 хв. 2-га група - діти, яким для реабілітації застосовували релаксуючий масаж (16 осіб) на ділянку спини, грудної клітки, поперекового відділу хребта. Масаж проводили щоденно, тривалістю 30 хв. 3-тя група - діти, яким для реабілітації застосовували 
лікувальну фізкультуру і масаж. Заняття здійснювали поперемінно через день, тривалістю 30 хв кожне.

Для анкетування була складена анкета, яка нараховувала 10 питань. У анкеті потрібно було дати відповіді на питання, пов'язані з симптомами розвитку сколіозу. Відповіді оцінювали за 4-бальною системою від 1 до 4 в міру погіршення стану дитини.

Статистичну обробку результатів досліджень здійснювали зі застосуванням непараметричних методів статистики.

Оглядовим методом було встановлено, що $45 \%$ дітей мали сколіотичну поставу, 15 \% дітей - сколіоз | ступеня, 25 \% - сколіоз || ступеня і лише 15 \% виявилися здоровими.

Для фізичної реабілітації дітей були застосовані лікувальна фізкультура та масаж. У дітей, яким була запропонована лікувальна фізкультура, позитивна динаміка відновлення постави розпочиналася вже на 2 тиждень занять, що проявлялося у зменшенні скарг дітей, поступовому відновленні положення голови, рівня розташування плечей, зменшенні сутулості та перекосу таза.

У дітей, яким застосовували масаж, позитивна динаміка відновлення постави була виявлена лише на 3 тиждень.

У дітей 3-ї групи, яким застосовували лікувальну гімнастику і масаж, відновлення постави розпочиналося вже на 10 день.

\section{СПИСОК ЛІТЕРАТУРИ}

1. Мухін В. М. Фізична реабілітація / В. М. Мухін. - К. : Олімпійська література, 2000. - 424 с.

2. Епифанов В. А. Реабилитация в травматологии / В. А. Епифанов, А. В. Епифанов. - М. : ГЭотАР-Медиа, 2010. - 331 с. - (Библиотека врача специалиста). - ISBN 978-5-9704-1685-3.

3. Основи діагностичних досліджень у фізичній реабілітації : навч. посіб. / Т. Бойчук, М. Голубєва, О. Леван-
Результати проведених досліджень свідчать, що у дітей з викривленням хребта лікувальна фізкультура була більш ефективною, ніж масаж тому, що застосовували ігровий метод, який заохочував дітей до руху.

Однак найефективнішим було поєднання лікувальної фізкультури і масажу, що проявилося у швидшому відновленні порушень постави, особливо, коли у дітей спостерігали початкові порушення постави, що свідчить про необхідність якнайшвидшого початку реабілітації таких дітей [5].

Результати анкетування, які провели після реабілітації дітей виявили позитивну динаміку покращення постави, зокрема лише в 35 \% дітей відзначали сколіотичну поставу, в 10 \% - сколіоз І ступеня, у 5 \% сколіоз II ступеня і в 50 \% не було ознак порушення постави. На сьогодні ми продовжуємо здійснювати реабілітацію дітей.

Висновки. 1. Для корекції порушень постави у дітей найефективнішим було поєднання лікувальної фізкультури і масажу, що проявилося у швидшому відновленні викривлень хребта, особливо, коли у дітей спостерігали початкові порушення.

2. Для дітей з порушеннями постави лікувальну фізкультуру доцільно застосовувати у вигляді ігор, які заохочують дітей до руху.

3. Корекцію порушень постави хребта доцільно розпочинати якнайшвидше.

довський [та ін.]. - Львів : ЗУКЦ, 2010. - 240 с. - ISBN 978-966-1518-64-2.

4. Порада А. М. Основи фізичної реабілітації : навч. посіб. / А. М. Порада, О. В. Солодовник, Н. Є. Прокопчук. - 2-ге вид. - К. : Медицина, 2008. - 246 с. - ISBN 9668144-26-0.

5. Профілактор Євмінова як засіб корекції порушень постави у школярів : навч. посіб. / П. Д. Плахтій, В. М. Мухін, В. В. Євмінов, І. О. Куделя. - Кам'янець-Подільський : [Абетка], 2006. - 159 с. - ISBN 966-682-281-4.

Отримано 15.01.19 